Nagel's plates. The 34 plates therefore adequately fulfil all the requirements of this type of investigation.

The German text has been translated by Professor James Drever, of Edinburgh.

\title{
OBITUARY
}

\section{CLAUD WORTH}

WE much regret to record the death of $\mathrm{Mr}$. Claud Worth which occurred at his Cornish home on June 24. He had retired from the practice of ophthalmology for some years, meaning to devote himself to his hobby of yacht sailing, but, unfortunately, an incurable disease prevented him from accomplishing as much as he would have liked.

Worth was a Lincolnshire man, and was born at Holbeach, the son of Thomas Mordaunt Worth, representative of an ancient Lincolnshire family. He was educated at Bedford and St. Bartholomew's Hospital. He qualified as M.R.C.S., L.R.C.P. in 1893, held house-surgeonship at a hospital in the Midlands, and proceeded to the F.R.C.S. in 1898. Worth began the study of ophthalmology under Henry Power and Bowater Vernon at St. Bartholomew's and joined the practice at Moorfields, where he worked in Holmes Spicer's clinic. He was elected to the honorary staff at Moorfields in 1906 and in due course became consulting surgeon. Hè was, for many years, ophthalmic surgeon to the West Ham Hospital, now the Queen Mary Hospital for the East End.

His work on Squint made Worth's name familiar all over the world. His well-known book, "Squint, its causes and treatment," has reached its 6 th edition and has been translated into many languages. And in the orthoptic treatment of Squint he was essentially a pioneer. Besides this he wrote a good text-book for students in conjunction with Dr. C. H. May.

Worth joined the Ophthalmological Society of the United Kingdom in 1899, and contributed many papers to its transactions. So far back as Vol. XXI he read a paper on the orthoptic treatment of Squint in Young Children. Worth's amblyoscope and "Fourlight test" are part of the armamentarium of every ophthalmic surgeon, and his advancement forceps was a notable advance over the old-fashioned Prince's forceps.

Worth was very successful in handling small children. Quiet and unassuming in manner, his gentleness to his patients endeared him to young and old alike. Children instinctively trusted him. 


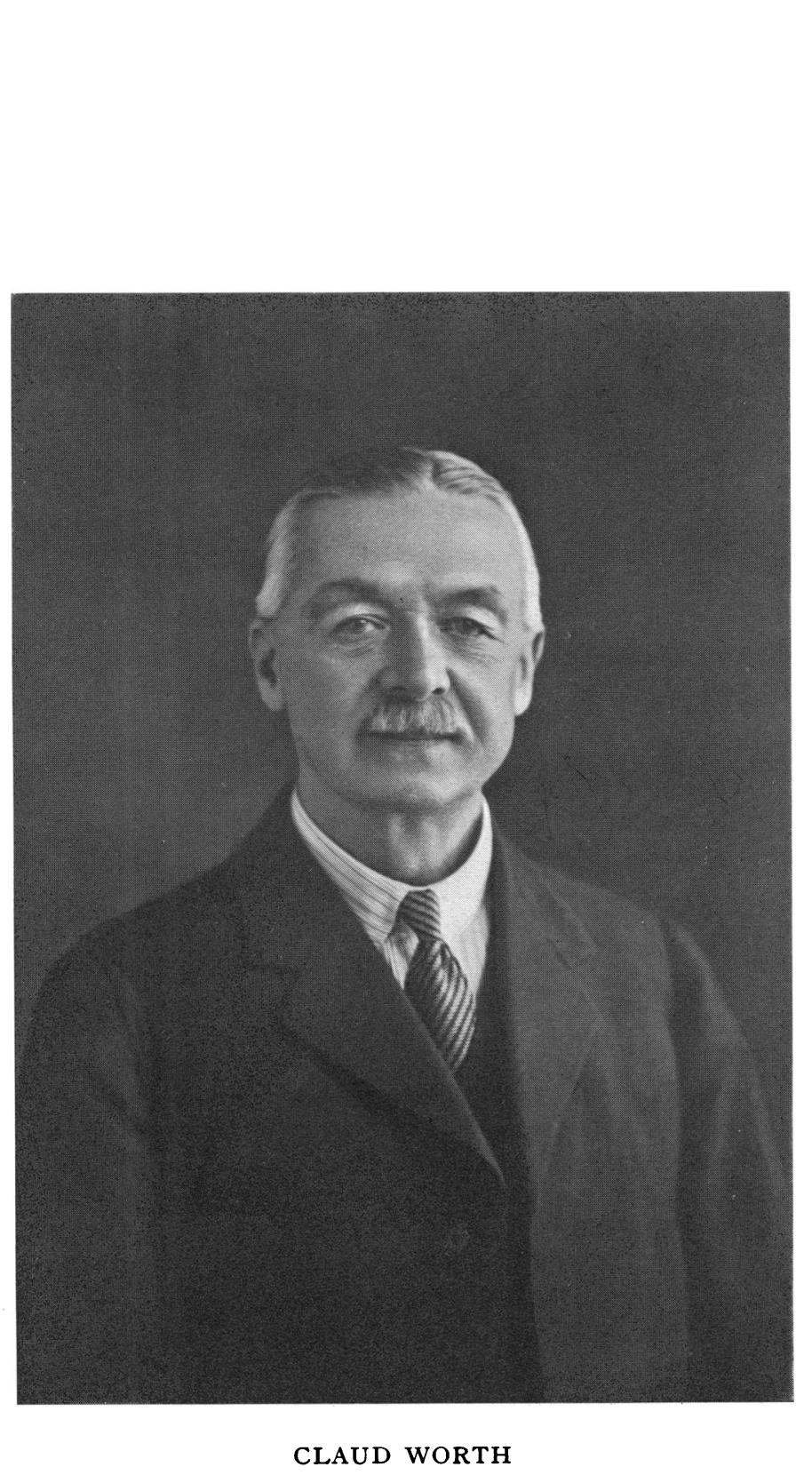

w

$c$

음

$\frac{\sqrt[3]{3}}{3}$

蛋

등

क्ष

ก)

$\overrightarrow{0}$

$\overrightarrow{\vec{\omega}}$

ळ

흥.

ก

6

ज

옥

0

Ф

त्ञ

궁

응 $\overrightarrow{0}$ 이 흑뭉 政 응

ڤ

$\stackrel{\mathbb{1}}{\varrho}$

혹

륨

흥

욱

응.

일

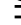

음

N

N

N

뭉

吕

$\stackrel{\mathbb{D}}{\stackrel{0}{\longrightarrow}}$

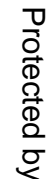


But, had he not made a name for himself in ophthalmology Worth's name would have been a household word wherever yachts are sailed. His love of the sea dated from childhood, and although he was prevented from entering the Royal Navy, his knowledge of seamanship, currents, harbours and all else that go to make up the science of yachting was immense. Ten years ago he sailed his own boat to the Azores. Worth was president of the Little Ship Club, and Vice-Commodore of the Royal Cruising Club, a master mariner and first class pilot. He also wrote books on yacht sailing which are classics. In 1910, "Yacht Cruising" was published, and it has now reached its fourth edition. In 1927 he published a companion volume, "Yacht Navigation and Voyaging." Some of his boats he designed himself and he proved the practicability of sailing small boats safely in deep water ; insisting that a suitable boat, manned by an efficient crew was perfectly safe, even for long voyages.

To his widow and son who survive him the sympathy of all ophthalmologists will be extended.

\section{NOTES}

Treacher Collins Memorial Fund
THE honorary treasurer of the Ophthalmological Society of the United Kingdom (Sir Arnold Lawson, K.B.E., 12, Harley Street, W.1) wishes to bring to the notice of those who still intend to contribute to this fund that the subscription list closes finally on September 30, 1936.
North of England Ophthalmological Society.

THE President of the North of England Ophthalmological Society for Session 19361937 is Mr. W. H. Kiep, 33, Manor Row, Bradford. Tenure of office from October 15.

\section{FUTURE ARRANGEMENTS}

\section{6}

October 6.-Midland Ophthalmological Society, at Birmingham Eye Hospital.

December 1.-Midland Ophthalmological Society, at Birmingham Eye Hospital. 